\title{
AGENCY COSTS,
} CAPITAL STRUCTURE AND CORPORATE PERFORMANCE: A SURVEY OF CROATIAN, SLOVENIAN AND CZECH LISTED COMPANIES

\begin{abstract}
Purpose: The aim of this study is, first to describe and explore equity agency costs; second, to explore the impact of capital structure on equity agency costs; and finally, to examine the impact of agency costs on the performance of listed companies.
\end{abstract}

Methodology: Panel data regression has been used for research data analysis.

Results: The results of the work show that equity to capital and long-term debt to capital variables have a positive and significant impact on the agency costs of listed companies in the Republic of Croatia. The study indicates that long-term debt to capital variable has a negative and significant impact on the agency costs of listed companies in Slovenia and the Czech Republic. Furthermore, we find evidence to suggest that changes in agency costs have little or no effect on the performance of listed companies in Croatia, Slovenia and the Czech Republic. The findings suggest that the capital structure decisions affect the agency costs of listed companies and the agency costs may affect corporate performance.

Conclusion: This study makes a number of contributions to the agency costs literature. It presents the first study of agency costs of listed companies in Croatia, Slovenia and the Czech Republic that uses panel data, a technique that enables us to isolate both cross section and time series effects. The present paper can help managers to better understand equity agency costs and their effects on corporate performance.

Keywords: Agency problems, agency costs, sales-to-asset ratio, capital structure, corporate performance 


\section{Introduction}

The idea of agency relationships emphasizes that managers, stockholders, bondholders and other parties act in their own self-interest and that costly conflicts may arise due to these self-interests. Shareholders face an agency problem in that their agents, the managers, may not act diligently on their behalf and may enjoy substantial salaries or excessive perquisites. The agency costs refer to costs that arise as a result of these conflicts between owners and managers. Jensen and Meckling (1976) point out that using debt helps to overcome the agency costs of equity. The need to make regular debt-service payments can discipline managers. Moreover, debt limits the management's ability to destroy value through perquisite consumption or lack of effort. Increased leverage also incurs costs and as leverage increases, the agency costs of debt rise (Jensen, 1986). The firm's value-maximizing capital structure will balance the agency costs of debt and equity with the other costs and benefits of debt.

Several seminal papers have provided the empirical framework for the main linkages between capital structure and agency costs. While there is a general consensus on the importance of capital structure for corporate agency costs, there is no agreement on the impact of corporate capital structure on such costs. Thus, there is a need for further research to provide a better understanding of equity agency costs and the impact that capital structure has on them. This paper addresses this gap to provide further evidence in the case of listed companies in Croatia, Slovenia and the Czech Republic. The present research focuses on examining the interplay of capital structure, equity agency costs and corporate performance in the three Member States of the European Union.

The aim of this paper is to contribute to the debate by empirically investigating the impact of capital structure on equity agency costs, as well as the impact of agency costs on the profitability and value of listed companies in Croatia, Slovenia and the Czech Republic. The purpose of this study is to give general recommendations for financial managers on how capital structure decisions should be made in order to reduce equity agency costs and improve corporate performance.

This study makes several contributions to the agency costs debate. First, it adds to the general debate about equity agency costs in the listed companies by showing how agency costs can affect corporate performance. More specifically, this is the first direct study of agency costs in Croatian listed companies. Furthermore, this is the first study of agency costs of listed companies in the three above-mentioned countries that uses panel data, a technique which enables us to isolate both cross-section and time-series effects. This is also the first study, to our knowledge, to investigate the impact of capital structure on agency costs, as well as the impact of agency costs on corporate performance in these three countries. Finally, the study also contributes to a better understanding of the relationship between agency costs and corporate performance in the Member States of the European Union that have undergone transition processes.

\section{Literature Review}

An agency problem arises when there is a conflict of interest between the agents and the principals. It may also arise due to asymmetric information. According to Jensen and Meckling (1976), if both parties to the relationship are utility maximizers, there is good reason to believe that the agent will not always act in the best interests of the principal. In most agency relationships, the principal and the agent will incur positive monitoring and bonding costs. In addition, there will be some divergence between the agent's decisions and the decisions, which would maximize the welfare of the principal. Shareholders face an agency problem in that their agents may not act diligently on their behalf. Managers may consume excessive wages or excessive perquisites; another issue might be if they are too conservative or too aggressive in their investment strategy. Agency costs can be defined as the sum of: the monitoring expenditures by the principal, the bonding expenditures by the agents and the residual loss.

The creditors of a corporation entrust their money to the managers, on the belief that the risks associated with debt securities will not increase substantially but managers could increase the wealth of the shareholders at the expense of the creditors by moving to a more risky asset structure. As the debt-to-total assets ratio increases, the agency costs of debt increase, and creditors will demand an interest rate that provides equilibrium return after agency costs (Seitz \& Ellison, 1995, p. 547). Jensen and Meckling (1976) find that managers of levered companies have an incentive to engage in asset sub- 
stitution and underinvestment. Asset substitution problem lies in promising to invest in a safe asset to obtain a return reflecting low risk but then substituting it with a riskier asset that offers the possibility of a higher return. The underinvestment problem occurs when the shareholders rationally forgo the project because they must invest the additional capital while all the benefits accrue to the creditors. Jensen $(1986,1993)$ suggests that debt servicing obligations help to discourage overinvestment of free cash flow. Myers (1977) suggests that short-term debt helps mitigate the agency costs of debt by resolving the underinvestment and asset substitution problems.

Jensen and Meckling (1976) point out that using debt helps overcome the agency costs of outside equity. Managers have an incentive to generate the financial resources needed to service the debt. When assessing how much debt to use, corporations have to consider the agency costs of increased debt. The agency costs associated with debt consist of: the opportunity wealth loss caused by the impact of debt on the investment decisions, the monitoring and bonding expenditures by the bondholders and the owner-manager, and the bankruptcy and reorganization costs.

Capital structure can balance out the conflict between shareholders and management, as well as that between shareholders and creditors. The agency costs of outside equity derive mainly from informational asymmetries and excessive perquisite consumption, while the agency costs of debt, though deriving from the same phenomena, are mainly related to risk incentives, investment incentives and bankruptcy costs (Moschandreas, 2000).

Ang et al. (2000) as well as Singh and Davidson (2003) argue that the sales-to-asset ratio measures the efficiency with which management uses the firm's assets to generate sales. A high asset turnover ratio shows a large amount of sales and ultimately cash flow that are generated for a given level of assets. A low ratio would indicate that management is using assets in non-cash flow generating and probably value destroying ventures. While a higher asset turnover may be identified with efficient asset management practices and hence shareholders value creation, a lower sales-to-asset ratio reflects asset deployment for unproductive purposes. Therefore, firms with a considerable amount of agency conflict will have lower asset turnover ratios relative to those having less agency conflict.
A higher level of debt may be used as a disciplinary method to reduce managerial cash flow waste through the threat of liquidation (Grossman \& Hart, 1982) or through pressure to generate cash flows to service debt (Jensen, 1986). Thus, debt will have a positive effect on the value of a corporation. According to Williams (1987), additional debt decreases agency costs. Opler and Titman (1993) argued that corporations that have high growth prospects are more likely to be better managed and less likely to have excess free cash flows because the available cash will be spent on positive net present value projects.

Most theoretical and empirical studies of agency costs have examined the impact of capital structure on such costs. Thus, several papers have provided the empirical framework for the main linkages between capital structure and agency costs. Singh and Davidson (2003) find that outside block ownership may have a limited effect on reducing agency costs. The results of $\mathrm{Li}$ and Cui (2003) indicate that firms with a higher debt-to-asset ratio have a higher ratio of sales to assets and a higher ratio of return on equity, and this relation is statistically significant. Harvey et al. (2004) provide new evidence that debt creates shareholder value for companies that face potentially high managerial agency costs.

There is a significant body of literature that shows that debt decreases rather than increases agency costs. Childs and Mauer (2008) find that financial flexibility stimulates taking on short-term debt resulting in a reduction in the agency costs. Florackis and Ozkan (2008) investigated the potential interactions between internal governance mechanisms and firm growth opportunities in determining agency costs. The results reveal that managerial ownership, managerial compensation and ownership concentration seem to play an important role in mitigating agency costs. Zhang and Li (2008) examined the impact of financial leverage on agency costs by conducting the multivariate and univariate tests based on data of UK listed companies; the findings suggest that leverage is negatively related to agency costs. McKnight and Weir (2009) find that changes in board structural characteristics have little or no effect on agency costs. Indeed, they find that firms with more debt tend to have lower agency costs and that debt reduces agency costs.

Wellalage and Locke (2012) investigated agency costs in 100 firms in New Zealand. The results indicate that the degree of owner involvement in 
the business influences firm agency costs. Nozari (2016) examined the impact of financial leverage on agency costs in listed manufacturing firms of Tehran Stock Exchange; the findings suggest that debt-to-equity and long-term debt ratios have a negative and significant impact on agency costs. Rashid (2016) points out that managerial ownership reduces the firm's agency costs only under the asset utilization ratio measure of agency costs.

Several researchers have examined the impact of agency costs on firm performance, but with divergent findings. Chi (2005) investigated the relation between firm value and the shareholder rights; the findings suggest that granting more rights to shareholders could be an effective way to reduce agency costs and enhance firm value. Nam and Wynne (2006) investigated the impact of agency costs on the value of single-segment and multi-segment firms; the findings suggest that firms with high equity-based compensation have higher valuation than firms with low equity-based compensation. Jiraporn and Tong (2007) investigated changes in firm value with respect to changes in debt maturity structure and found consistent evidence that shortterm debt enhances firm value. Xiao (2009) finds that agency costs have a negative and significant impact on firm value. Wang (2010) investigated how agency costs influence firm performance; the findings suggest that agency costs have a negative and significant impact on firm performance. Jabbary et al. (2013) examined the impact of agency costs on the performance of listed firms. The results reveal a significant relationship between agency costs and firm performance.

Dawar (2014) investigated empirically the impact of capital structure choice on firm performance in India based on the agency theory. The findings suggest that leverage has a negative influence on financial performance of Indian firms. Colombo et al. (2014) used the lens of the resource-based view and horizontal agency cost theory to examine the effect of ownership structure on the performance of Italian high-tech entrepreneurial firms. The results indicate that the number of owner-managers has a positive effect on firm performance, whereas the effect of the number of non-manager individual shareholders is negligible. While owner-managers engender low horizontal agency costs, non-manager individual shareholders generate high horizontal agency problems because of their limited managerial involvement. Moscu (2014) examined the rela- tionship between capital structure and profitability of Romanian listed companies. The results indicate that firm's performance measured by ROA, ROE, RCA and MBR is significantly influenced by capital structure.

Savitri (2018) examined the relationship between family ownership agency costs, financial performance and companies' business strategies. The findings suggest that agency costs influence business strategy and financial performance, which shows that agency costs contribute to both the increase and decrease of financial performance. Pandey and Sahu (2019) examined the relationship among debt financing, agency costs and the performance of Indian firms. The findings suggest a significant and negative effect of debt on firm performance. The magnitude of debt is also found to be positively affecting agency costs.

Imelda and Dewi (2019) investigated the impact of capital structure and corporate governance on agency costs. Capital structure is measured by debt-to-asset ratio and long-term debt-to-asset ratio. The results reveal that debt-to-asset ratio has a significant impact on agency costs, while the longterm debt-to-asset ratio, managerial ownership, and board size do not have a significant impact on such costs. Anh and Thao (2019) examined the impact of capital structure on firm performance of Vietnamese listed companies based on agency cost theory. The findings suggest that there is an inverse $\mathrm{U}$-shaped relationship between leverage and return on equity (ROE).

Khan et al. (2020) investigate the effect of corporate governance quality and ownership structure on the relationship between the agency costs and firm performance. The results indicate that the agency-performance relationship is positively affected by corporate governance quality, ownership concentration, and non-state ownership. State ownership has a negative effect on the agencyperformance relationship. The analysis adds to the empirical literature on agency theory by providing useful insights into how corporate governance and ownership concentration can help modify the agency-performance relationship. Hundal (2020) examines the association between the Economic Value Added (EVA) and the firm decision-making and performance, and the interplay between the EVA and agency costs. The findings suggest that the EVA provides a broader basis of measurement of ef- 
ficiency and motivates managers to make efficient utilization of funds.

Previous empirical studies have presented a variety of viewpoints regarding capital structure decisions and agency costs, the difference between their empirical results being attributable to the differences in databases, time periods and the respective specificities of each country. However, these studies failed to explore agency costs thoroughly. Furthermore, there is a gap in the empirical literature regarding the issue of agency costs in the context of Croatian, Slovenian and Czech listed companies. Our research contributes to the empirical literature by bridging this gap.

\section{Research}

\subsection{Methodology and data}

In this research, we used data from three members of the European Union: the Republic of Croatia, the Republic of Slovenia and the Czech Republic. Croatia and Slovenia have been chosen for a comparative analysis because they were once part of the same country and consequently followed similar economic and political patterns for a long time. The Czech Republic, on the other hand, has been chosen for this comparative analysis because all three countries, i.e. the Czech Republic, Slovenia and Croatia, were formed as a result of the split of their former countries that used to belong to the same socio-economic system, and have undergone transition processes.

This paper presents results from the empirical research undertaken on a representative sample of Croatian, Slovenian and Czech listed companies with the aim of exploring the impact of capital structure on agency costs and the impact of agency costs on corporate performance. Our initial sample was constructed from 228 listed companies. From the sample, companies that belong to the financial and governmental sectors were excluded because of additional requirements that apply to these sectors. Companies showing extreme or inconsistent figures in any of the variables were also excluded from the sample. The final sample consisted of a balanced panel of 143 companies listed in the period from 2009 to July 1, 2013, when Croatia joined the European Union. Therefore, we cannot take into consideration a longer period of time or attempt to implement the analysis with more current data. However, we believe that our empirical contribution will al- low future contributions to compare the impact of capital structure on agency costs, as well as the impact of agency costs on corporate performance across different scenarios after the year 2013.

Statistical data analysis was carried out using Stata program version 15.0. Panel data regression was used for research data analysis, and constant coefficients (pooled) regression models, fixed-effects models and random-effects models were considered. If there is significant cross sectional or significant temporal effect, we cannot assume a constant intercept $\alpha$ for all the companies and years; rather we have to consider the one-way or two-way error components model. We have a fixed effect model if the errors are assumed to be fixed. Fixed effects explore the relationship between predictor and outcome variables within an entity. The fixed effects model is considered under two assumptions: heterogeneous intercepts and homogeneous slope, and heterogeneous intercepts and slopes. Fixed effects remove the effect of the time-invariant characteristics so we can assess the net effect of the predictors on the outcome variable. The fixed effects model can be expressed as follows:

$Y_{i t}=\alpha_{i}+\beta \times x_{i t}+v_{i t}$

$\mathrm{i}=1,2, \ldots, \mathrm{N} ; \mathrm{t}=1,2, \ldots, \mathrm{T}$.

where $\alpha_{i}$ is the unknown intercept for each entity, $Y_{i t}$ is the dependent variable where $\mathrm{i}=$ entity and $\mathrm{t}$ $=$ time, $X_{\mathrm{it}}$ represents one independent variable, $\beta$ is the coefficient for the independent variable and $v_{i t}$ is the error term. Random effects model is a linear model that assumes that the criteria for unit inclusion correspond to randomness principles. In random effects model, we wish to treat the parameter vector as a realization in each panel of a stochastic process. The variation across entities is assumed to be random and uncorrelated with the predictor or independent variables included in the model. Random effects assume that the entity's error term is not correlated with the predictors, which allows for time-invariant variables to play a role as explanatory variables. The random effects model can be expressed as follows:

$Y_{i t}=\alpha+\beta \times x_{i t}+u_{i t}+\varepsilon_{i t}$ $\mathrm{i}=1,2, \ldots, \mathrm{N} ; \mathrm{t}=1,2, \ldots, \mathrm{T}$.

where $\alpha$ is the unknown intercept for each entity, $Y_{\text {it }}$ is the dependent variable where $\mathrm{i}=$ entity and $\mathrm{t}=$ time, $X_{i t}$ represents one independent variable, $\beta$ is the 
coefficient for that variable, $\mathrm{u}_{\mathrm{it}}$ between entity error and within entity error (Vijayamohanan, 2016).

In this section, an overview of the variables that were used in our empirical analysis is provided:

(1) Equity to Capital = Equity/Total Capital Employed

(2) Retained Earnings to Capital = Retained earnings/Total Capital Employed

(3) Long-term Debt to Capital = Long-term debt/Total Capital Employed

(4) Agency costs are measured as

- Asset Utilization Ratio = Annual Sales/Total Assets

(5) Profitability is measured as

- Return on Assets (ROA)

(6) Firm value is measured as

- Sustainable Owners Value Added Ratio = Earnings Before Interest and Taxes * (1Profit Tax) / (Capital and Retained Earnings " Interest Rate on Deposits) (Belak, 2014, pp. 201-203).

The sales-to-asset ratio is used as a proxy for equity agency costs. This ratio is a measure of how effectively the firm's management deploys its assets and agency costs are inversely related to the sales-toasset ratio. The sales-to-asset ratio has been used in two US studies as a direct measure of agency costs, Ang et al. (2000) and Singh and Davidson (2003). Both studies argue that the sales-to-asset ratio measures the efficiency with which management uses the firm's assets to generate sales. A high ratio shows that assets are generating significant sales and therefore suggests low agency costs. In contrast, a low ratio shows that management is implementing policies such as poor investment decisions or consuming excessive perquisites. A low sales-to-asset ratio indicates high agency costs and inefficient asset utilization. McKnight and Weir (2009) argue, as do Ang et al. (2000) and Singh and Davidson (2003), that the sales-to-asset ratio provides a useful indicator of agency costs.

\subsection{Results of empirical analysis}

Based on a sample of listed companies in Croatia, Slovenia and the Czech Republic, we investigated the impact of capital structure on agency costs, as well as the impact of agency costs on corporate performance.

\subsubsection{The impact of capital structure on agency costs}

Our central research question is the effect of different components of capital structure on equity agency costs. The proxies for capital structure are the following: equity to total capital, retained earnings to total capital and long-term debt to total capital ratios. The ratio of annual sales to total assets is used as an inverse proxy for equity agency costs. In interpreting these results, it is important to remember that the sales-to-asset ratio varies inversely with equity agency costs. The impact of capital structure on the agency costs of listed companies in Croatia has been analyzed, as shown in Table 1 .

Table 1 Regression results with Fixed Effects Model for listed companies in Croatia

\begin{tabular}{|l|c|c|c|c|c|c|}
\hline Independent variables & $\begin{array}{c}\text { Coeffi- } \\
\text { cient }\end{array}$ & $\begin{array}{c}\text { Standard } \\
\text { Error }\end{array}$ & $\begin{array}{c}\text { t-Sta- } \\
\text { tistic }\end{array}$ & p-value & $\begin{array}{c}\text { 95\% Confidence } \\
\text { Interval Lower }\end{array}$ & $\begin{array}{c}\text { 95\% Confidence } \\
\text { Interval Upper }\end{array}$ \\
\hline Equity to capital & -.4219 & .0501 & -8.41 & 0.000 & -.5202 & -.3236 \\
\hline Retained earnings to capital & -.0001 & .0001 & -0.49 & 0.624 & -.0002 & .0001 \\
\hline Long-term debt to capital & -.3945 & .0631 & -6.25 & 0.000 & -.5182 & -.2707 \\
\hline Constant & .6922 & .0314 & 22.04 & 0.000 & .6305 & .7537 \\
\hline
\end{tabular}

Dependent variable: Sales-to-Asset Ratio

$\mathrm{R}^{2}=0.166$

F test: $\mathrm{F}(88,353)=49.93$; Prob $>\mathrm{F}=0.000$

Breusch-Pagan test: chibar2 $(01)=694.03$; Prob $>$ chibar2 $=0.000$

Hausman test: $\operatorname{chi} 2(3)=18.56$; Prob $>$ chi $2=0.0003$

White test: chi 2 (9) = 21.00; Prob $>$ chi $2=0.0127$

Wooldridge test: $\mathrm{F}(1,88)=22.67$; Prob $>\mathrm{F}=0.000$

Source: Author's calculations 
This study investigated the impact of capital structure on equity agency costs of listed companies in Croatia. Using the Hausman test and the F test, the fixed effects model has been selected as the efficient and consistent model for the variable salesto-asset ratio. Agency costs are inversely related to the sales-to-asset ratio. The regression coefficients reported for equity to capital and long-term debt to capital variables in the fixed effects model are negative, which may be an indication that these capital structure components have a negative and significant impact on the sales-to-asset ratio, as well as a positive and significant impact on the agency costs of listed companies in Croatia, because equity agency costs are inversely related to the sales-toasset ratio.

The impact of capital structure changes on equity agency costs of listed companies in Slovenia has been investigated and the results of panel regression analysis are presented in Table 2 .

Table 2 Regression results with Random Effects Model for listed companies in Slovenia

\begin{tabular}{|l|c|c|c|c|c|c|}
\hline Independent variables & $\begin{array}{c}\text { Coeffi- } \\
\text { cient }\end{array}$ & $\begin{array}{c}\text { Standard } \\
\text { Error }\end{array}$ & $\begin{array}{c}\text { t-Statis- } \\
\text { tic }\end{array}$ & p-value & $\begin{array}{c}\text { 95\% Confidence } \\
\text { Interval Lower }\end{array}$ & $\begin{array}{c}\text { 95\% Confidence } \\
\text { Interval Upper }\end{array}$ \\
\hline Equity to capital & -.7846 & .1564 & -5.01 & 0.000 & -1.0913 & -.4779 \\
\hline Retained earnings to capital & -.2104 & .0678 & -3.10 & 0.002 & -.3434 & -.0774 \\
\hline Long-term debt to capital & .1505 & .0342 & 4.39 & 0.000 & .0833 & .2176 \\
\hline Constant & .8529 & .0461 & 18.49 & 0.000 & .7625 & .9434 \\
\hline
\end{tabular}

Dependent variable: Sales-to-Asset Ratio

$\mathrm{R}^{2}=0.1738$, F test: $\mathrm{F}(28,113)=28,56 ;$ Prob $>\mathrm{F}=0.0000$, Breusch Pagan test: chibar2 $(01)=196.08 ;$ Prob $>$ chibar2 $=0.0000$

Hausman test: chi2(3) = 2.01; Prob $>$ chi $2=0.5705$, White test: chi $2(9)=17.94$; Prob $>$ chi $2=0.0359$

Wooldridge test: $\mathrm{F}(1,28)=1.414 ;$ Prob $>\mathrm{F}=0.2444$

Source: Author's calculations

Using the Hausman test and Breusch-Pagan Lagrange Multiplier test, the random effects model has been selected as the efficient and consistent model for the dependent variable sales-to-asset ratio. The regression coefficients reported for equity to capital and retained earnings to capital variables in the random effects model are negative and statistically significant at the $1 \%$ level, which may be an indication that these capital structure components have a negative and significant impact on the salesto-asset ratio, as well as a positive and significant impact on the equity agency costs of listed companies in Slovenia. The regression coefficient reported for long-term debt to capital variable in the random effects model is positive and statistically significant, which indicates that long-term debt to capital variable has a positive and significant impact on the sales-to-asset ratio, as well as a negative and significant impact on the equity agency costs of listed companies in Slovenia, because equity agency costs are inversely related to the sales-to-asset ratio. As regards Slovenia, the findings suggest that increasing long-term debt financing to some extent can decrease equity agency costs of listed companies.

The impact of capital structure on equity agency costs of Czech listed companies has been examined and the results of panel regression analysis are presented in Table 3.

\section{Table 3 Regression results with Fixed Effects Model for listed companies in the Czech Republic}

\begin{tabular}{|l|c|c|c|c|c|c|}
\hline Independent variables & $\begin{array}{c}\text { Coef- } \\
\text { ficient }\end{array}$ & $\begin{array}{c}\text { Standard } \\
\text { Error }\end{array}$ & t-Statistic & $\begin{array}{c}\text { p- } \\
\text { value }\end{array}$ & $\begin{array}{c}\text { 95\% Confidence } \\
\text { Interval Lower }\end{array}$ & $\begin{array}{c}\text { 95\% Confidence } \\
\text { Interval Upper }\end{array}$ \\
\hline Equity to capital & -.0019 & .1414 & -0.01 & 0.989 & -.2792 & .2753 \\
\hline Retained earnings to capital & .2973 & .1549 & 1.92 & 0.055 & -.0062 & .6009 \\
\hline Long-term debt to capital & .2947 & .1421 & 2.07 & 0.038 & .0161 & .5733 \\
\hline Constant & .2339 & .0907 & 2.58 & 0.010 & .0561 & .4118 \\
\hline
\end{tabular}

Dependent variable: Sales-to-Asset Ratio

$\mathrm{R}^{2}=0.1743$, F test: $\mathrm{F}(23,69)=20.78 ;$ Prob $>\mathrm{F}=0.0000$, Breusch Pagan test: chibar2 $(01)=87.03$; Prob $>$ chibar2 =0.0000 Hausman test: chi2 $(1)=7.39$; Prob $>$ chi2 $=0.0065$, White test: chi $2(9)=17.43$; Prob $>$ chi $2=0.0424$

Wooldridge test: $\mathrm{F}(1,23)=7.310$; Prob $>\mathrm{F}=0.0127$

Source: Author's calculations 
Using the Hausman test and the F-test, the fixed effects model has been selected as the efficient and consistent model for the variable sales-to-asset ratio. Agency costs are inversely related to the salesto-asset ratio. The regression coefficients reported for retained earnings to capital and long-term debt to capital variables in the fixed effects model are positive and statistically significant at the $5 \%$ level, which may be an indication that these capital structure components have a positive and significant impact on the sales-to-asset ratio, as well as a negative impact on the equity agency costs of Czech listed companies. Likewise, we have found evidence that as the long-term debt to capital variable increases, the equity agency costs of Czech listed companies tend to decrease.

\subsubsection{The impact of agency costs on corporate perfor- mance}

In this work, we also investigated the impact of equity agency costs on the profitability and value of listed companies in Croatia, Slovenia and the Czech Republic. Sustainable Owners Value Added Ratio and Return on Assets are used as proxies for firm value and profitability. The proxy for equity agency costs is the sales-to-asset ratio. The obtained results for examined listed companies are compared as given in Table 4.

Table 4 Comparison of the regression results of the impact of agency costs on firm performance

\begin{tabular}{|c|c|c|c|}
\hline Independent variable & Coefficients & $\begin{array}{l}\text { Standard } \\
\text { Error }\end{array}$ & p-value \\
\hline \multicolumn{4}{|l|}{ The Republic of Croatia } \\
\hline $\begin{array}{l}\mathrm{R}^{2}=0.0025 \\
\text { Random Effects Model }\end{array}$ & Dependent variable: Return on Assets & & \\
\hline $\begin{array}{l}\text { Sales-to-Asset Ratio } \\
\text { Constant }\end{array}$ & $\begin{array}{l}.0068 \\
-.0138 \\
\end{array}$ & $\begin{array}{l}.0167 \\
.0099 \\
\end{array}$ & $\begin{array}{l}0.684 \\
0.161 \\
\end{array}$ \\
\hline $\begin{array}{l}\mathrm{R}^{2}=0.0002 \\
\text { OLS Model }\end{array}$ & $\begin{array}{l}\text { Dependent variable: } \\
\text { Sustainable Owners Value Added Ratio }\end{array}$ & & \\
\hline $\begin{array}{l}\text { Sales-to-Asset Ratio } \\
\text { Constant }\end{array}$ & $\begin{array}{l}-7.9524 \\
2.4274\end{array}$ & $\begin{array}{l}6.7710 \\
6.2956\end{array}$ & $\begin{array}{l}0.240 \\
0.700\end{array}$ \\
\hline \multicolumn{4}{|l|}{ The Republic of Slovenia } \\
\hline $\begin{array}{l}\mathrm{R}^{2}=0.0072 \\
\text { Random Effects Model }\end{array}$ & Dependent variable: Return on Assets & & \\
\hline $\begin{array}{l}\text { Sales-to-Asset Ratio } \\
\text { Constant }\end{array}$ & $\begin{array}{l}.0140 \\
-.0153\end{array}$ & $\begin{array}{l}.0210 \\
.0180\end{array}$ & $\begin{array}{l}0.505 \\
0.397\end{array}$ \\
\hline $\begin{array}{l}\mathrm{R}^{2}=0.2270 \\
\text { Random Effects Model }\end{array}$ & $\begin{array}{l}\text { Dependent variable: } \\
\text { Sustainable Owners Value Added Ratio }\end{array}$ & & \\
\hline $\begin{array}{l}\text { Sales-to-Asset Ratio } \\
\text { Constant }\end{array}$ & $\begin{array}{l}.7798 \\
.8920 \\
\end{array}$ & $\begin{array}{l}.3970 \\
.3558\end{array}$ & $\begin{array}{l}0.049 \\
0.012\end{array}$ \\
\hline \multicolumn{4}{|l|}{ The Czech Republic } \\
\hline $\begin{array}{l}\mathrm{R}^{2}=0.0710 \\
\text { Random Effects Model }\end{array}$ & Dependent variable: Return on Assets & & \\
\hline $\begin{array}{l}\text { Sales-to-Asset Ratio } \\
\text { Constant }\end{array}$ & $\begin{array}{l}.0231 \\
.0499\end{array}$ & $\begin{array}{l}.0061 \\
.0119\end{array}$ & $\begin{array}{l}0.000 \\
0.000\end{array}$ \\
\hline $\begin{array}{l}\mathrm{R}^{2}=0.0103 \\
\text { OLS Model }\end{array}$ & $\begin{array}{l}\text { Dependent variable: } \\
\text { Sustainable Owners Value Added Ratio }\end{array}$ & & \\
\hline $\begin{array}{l}\text { Sales-to-Asset Ratio } \\
\text { Constant }\end{array}$ & $\begin{array}{l}1.6507 \\
3.4178\end{array}$ & $\begin{array}{l}1.6694 \\
1.2333\end{array}$ & $\begin{array}{l}0.325 \\
0.007\end{array}$ \\
\hline
\end{tabular}

Source: Author's calculations 
The regression coefficients reported for sales-toasset ratio are positive for Croatian and Slovenian listed companies, which may be an indication that the sales-to-asset ratio has a positive but not significant impact on the profitability of listed companies, while agency costs have a negative impact on the profitability of listed companies in Croatia and Slovenia. This study has empirically examined the impact of agency costs on the profitability of listed companies in the Czech Republic. The regression coefficient reported for sales-to-asset ratio in the random effects model is positive and statistically significant at the $1 \%$ level, which indicates that the sales-to-asset ratio has a positive and significant impact on the Return on Assets, while agency costs have a negative and significant impact on the profitability of listed companies in the Czech Republic.

Our analysis does not indicate the existence of an interaction effect between agency costs and the value of listed companies in Croatia. As regards Slovenia, the study has examined the impact of equity agency costs on the value of listed companies measured by Sustainable Owners Value Added Ratio. Using the Hausman test and Breusch-Pagan Lagrange Multiplier test, the random effects model has been selected as the efficient and consistent model for the variable Sustainable Owners Value Added Ratio. The regression coefficient reported for sales-to-asset ratio in the random effects model is positive and statistically significant at the $5 \%$ level, which may be an indication that the sales-to-asset ratio has a positive and significant impact on the Sustainable Owners Value Added Ratio, while agency costs have a negative and significant impact on the value of Slovenian listed companies when measured by Sustainable Owners Value Added Ratio. On the other hand, the findings for the Czech Republic indicate that the impact of equity agency costs on the value of listed companies measured by Sustainable Owners Value Added Ratio is not statistically significant. The regression coefficient reported for sales-toasset ratio in the Ordinary Least Squares Model is positive but not significant, which indicates that the sales-to-asset ratio has a positive but not significant impact on the Sustainable Owners Value Added Ratio, while agency costs have a negative impact on the value of Czech listed companies.

\section{Discussion}

This paper addresses the issue of how capital structure components affect equity agency costs and how corporate performance can be influenced by agency costs. In contrast to previous empirical studies that focus only on total debt, short-term debt and longterm debt ratios as measures of capital structure, the present study takes into account different components of capital structure that may affect equity agency costs. This study complements the agency theory literature by investigating the impact of outside equity, inside equity and long-term debt on equity agency costs, as well as the impact of agency costs on corporate performance. Consequently, our findings expand upon previous research. To measure equity agency costs of the listed companies, we have used the asset utilization ratio. Our measure of equity agency costs is a proxy for the loss in revenues attributable to inefficient asset utilization, which can result from poor investment decisions, e.g. investing in negative net-present-value assets, or from management's shirking, e.g. exerting too little effort to generate revenue.

The results reveal that equity to capital and longterm debt to capital variables in the fixed effects model are negative, which may be an indication that these capital structure components have a negative and significant impact on the sales-to-asset ratio, as well as a positive and significant impact on the agency costs of listed companies in Croatia. As regards Slovenia, the findings suggest that equity to capital and retained earnings to capital variables have a negative and significant impact on the sales-toasset ratio, as well as a positive impact on the equity agency costs of listed companies. This indicates that as values of equity to capital and retained earnings to capital variables increase, the equity agency costs of listed companies tend to increase. It is evident from the results that long-term debt to capital variable has a negative impact on equity agency costs indicating that as long-term debt to capital variable increases the equity agency costs of listed companies in Slovenia tend to decrease. This phenomenon may be explained by the fact that using long-term debt helps overcome the agency costs of outside equity. The important benefit of using long-term debt is that it reduces managerial perquisite consumption as the need to make regular debt-service payments effectively disciplines managers. If managers do not operate the corporation well enough to cover the debt-service payments, creditors can force the corporation into bankruptcy and take control of it. Our results are consistent with the theory that debt can reduce the agency costs of free cash flow 
by reducing the cash flow available for spending at the discretion of managers (Jensen, 1986) and that additional debt decreases agency costs (Williams, 1987). This study finds that retained earnings to capital and long-term debt to capital variables have a positive impact on the sales-to-asset ratio, as well as a negative impact on equity agency costs indicating that as values of retained earnings to capital and long-term debt to capital variables increase, the agency costs of listed companies in the Czech Republic tend to decrease. Our results further indicate that using debt and retained earnings helps overcome the agency costs of equity. Therefore, it should be noted that inconsistent results on the effect of capital structure on equity agency costs are obtained for listed companies in Croatia, Slovenia and the Czech Republic.

To summarize, we have found some evidence that long-term debt reduces the agency costs of equity. These costs arise because the managers make poor investment decisions, exert insufficient effort, which results in lower revenues, and consume executive perquisites. The magnitude of agency costs is determined by how well the owners and creditors monitor the actions of the outside managers. Our paper suggests that long-term debt reduces the agency costs of equity, since debt-servicing requirements can limit management's ability to pursue positive net present value projects.

This study suggests that the effect of agency costs on corporate performance differs in the European Union. Using a number of performance measures, we find that changes in agency costs have little or no effect on the performance of listed companies in Croatia, Slovenia and the Czech Republic. The results imply that the agency costs of equity have a negative but not significant impact on the Return on Assets Ratio of listed companies in Croatia and Slovenia. The agency costs have a negative and significant impact on the Return on Assets Ratio of listed companies in the Czech Republic indicating that as the value of agency costs increases, the value of Return on Assets Ratio of listed companies tends to decrease.

Regarding the impact of agency costs on the value of listed companies in Slovenia, the findings reveal that equity agency costs have a negative and statistically significant impact on the variable Sustainable Owners Value Added Ratio indicating that as the value of agency costs increases, the value of Sustainable Owners Value Added Ratio tends to decrease. These results appear consistent with the results of Xiao's (2009) study, which found that agency costs have a negative and significant impact on firm value. This study also finds that the sales-toasset ratio has a positive but not significant impact on the value of listed companies, while agency costs have a negative but not significant impact on corporate value in the Czech Republic.

Regarding the impact of long-term debt on the equity agency costs of the Slovenian and Czech listed companies examined in our study, we have found it to be negative, meaning that a higher level of longterm debt leads to a lower level of agency costs. As the amount of long-term debt increases, the expected agency costs of equity decrease, while the value of the Slovenian and Czech listed companies increases, which makes long-term debt a reasonable option to finance their growth. Membership in the European Union may have an impact on the capital structure, agency costs and financial performance of listed companies: older Member States have greater financial stability, fewer funding constraints and lower risks. Although the selected countries are now members of the European Union, inconsistent results on the effect of capital structure on agency costs and the effect of agency costs on corporate value are obtained for them in the study. Croatia's economic performance fell short of its potential during the war that raged there in early 1990s, but the country also become a member of the European Union later than Slovenia or the Czech Republic; hence the difference in the respective impact of capital structure on agency costs.

\section{Conclusion}

This paper highlights the importance of equity agency costs and their impact on corporate performance. The study has empirically examined the impact of capital structure components on the equity agency costs of listed companies in Croatia, Slovenia and the Czech Republic. The empirical results indicate that changes in the capital structure affect equity agency costs differently in the examined listed companies in the European Union. The results indicate that equity to capital and long-term debt to capital variables have a negative and significant impact on the sales-to-asset ratio, as well as a positive and significant impact on the equity agency costs of listed companies in Croatia. The findings reveal that equity to capital, retained earnings to capital and long-term debt to capital variables are signifi- 
cant determinants of equity agency costs in Slovenia, while long-term debt to capital variable is a significant determinant of equity agency costs in the Czech Republic. The results appear consistent with the results of Li and Cui (2003) and Nozari (2016) studies, which found that debt reduces agency costs. Indeed, the results obtained in this study lead to the conclusion that the capital structure decisions affect the equity agency costs of listed companies. Furthermore, there seems to be a negative association between agency costs and corporate value in Slovenia and the Czech Republic. We find evidence to suggest that changes in agency costs have little or no effect on performance of listed companies in Croatia, Slovenia and the Czech Republic.

Our study makes several important contributions to academics and managers. First, this paper contributes to the agency theory literature by conducting an empirical study on the relation between capital structure and the existence of equity agency costs, as well as the relation between equity agency costs and corporate performance. Second, our paper can help managers to better understand equity agency costs by showing them how their existence affects corporate performance. Our findings have potentially important implications for managers. They indicate that managers should aim to keep as close to the optimal debt-equity level as possible, and try to avoid any deviation in order to minimize the agency costs of equity as well as the agency costs of debt. In this work, we have not examined the impact of debt agency costs on corporate performance that remains an open question.

As a limitation of the present study, it should be noted that it is based on the secondary data taken from the published annual reports of the selected companies, and on ratio analysis, which has its own limitations. The results are limited to the countries analyzed and another constraint is a short time series of the data used. Future research should extend its analysis to a representative sample of listed companies in the European Union and a long time series of data. Further analysis might focus on a range of agency costs measures and different aspects of corporate performance. 


\section{REFERENCES}

1. Ang, J. S., Cole, R. \& Lin, J. W. (2000). Agency Costs and Ownership Structure. The Journal of Finance, 55(1), 81-106. https://doi.org/10.1111/0022-1082.00201

2. Anh, N. T. \& Thao, T. T. P. (2019). The impact of capital structure on firm performance of Vietnamese non-financial listed companies based on agency cost theory. VNU Journal of Science: Economics and Business, 35(2), 24-33. https://doi.org/10.25073/2588-1108/vnueab.4212

3. Belak, V. (2014). Analiza poslovne uspješnosti. Računovodstvo, revizija i financije.

4. Childs, P. D. \& Mauer, D. C. (2008). Managerial Discretion, Agency Costs and Capital Structure. https://doi.org/10.2139/ssrn.1108218

5. Colombo, M. G., Croce, A. \& Martinu, S. (2014). Ownership structure, horizontal agency costs and the performance of high-tech entrepreneurial firms. Small Business Economics, 42(2), 265-282.

https://doi.org/10.1007/s11187-013-9483-y

6. Dawar, V. (2014). Agency theory, capital structure and firm performance: Some Indian Evidence. Managerial Finance, 40(12), 1190-1206. https://doi.org/10.1108/MF-10-2013-0275

7. Grossman, S. \& Hart, O. (1982). Corporate Financial Structure and Managerial Incentives. In McCall, J. (Ed.), The Economics of Information and Uncertainty (pp. 107-140). University of Chicago Press.

8. Harvey, R. C., Lins, K. V. \& Roper, H. A. (2004). The Effect of capital structure when expected agency costs are extreme. Journal of Financial Economics, 74(1), 3-30.

https://doi.org/10.1016/j.jfineco.2003.07.003

9. Hundal, S. (2015). Economic Value Added (EVA), Agency Costs and Firm Performance: Theoretical Insights through the Value Based Management (VBM) Framework. Finnish Business Review. http:// urn.fi/urn:nbn:fi:jamk-issn-2341-9938-5/

10. Imelda, E. \& Dewi, A. P. (2019). Capital structure, corporate governance and agency costs. In Manzano, J. A. et al. (Eds.). Proceedings of the $7^{\text {th }}$ International Conference on Entrepreneurship and Business Management (pp. 203-207). Jakarta: Universitas Tarumanagara. https://doi.org/10.5220/0008490602030207

11. Jabbary, H., Hasiha, Z. \& Labesmka, R. H. (2013). Investigation of the effect of agency costs on firm performance of listed firms in Tehran Stock Exchange. European Online Journal of Natural and Social Sciences, 2(3), 771-776.

12. Jensen, M. C. \& Meckling, W. (1976). Theory of the Firm: Managerial Behavior, Agency Costs and Ownership structure. Journal of Financial Economics, 3(4), 305-360.

13. Jensen, M. C. (1986). The Agency Cost of Free Cash Flow: Corporate Finance and Takeovers. American Economic Review, 76(2), 323-329. https://doi.org/10.1016/0304-405X(76)90026-X

14. Jiraporn, P. \& Tong, S. (2007). Debt Maturity Structure, Agency Costs and Firm Value: Evidence from 1973-2004 (Working Paper).

15. Khan, H. R., Khidmat, W. B., Al Hares, O., Muhammad, N. \& Saleem, K. (2020). Corporate governance quality, ownership structure, agency costs and firm performance. Evidence from emerging economy. Journal of Risk and Financial Management, 13(7), 154-187. https://doi.org/10.3390/jrfm13070154

16. Li, H. \& Cui, L. (2003). Empirical Study of Capital Structure on Agency Costs in Chinese Listed Firms. Nature and Science, 1(1), 12-20.

17. McKnight, P. J. \& Weir, C. (2009). Agency costs, corporate governance mechanisms and ownership structure in large UK publicly quoted companies: A panel data analysis. The Quarterly Review of Economics and Finance, 49(2), 139-158. https://doi.org/10.1016/j.qref.2007.09.008

18. Moschandreas, M. (2000). Business Economics. Thomson.

19. Moscu, R. G. (2014). Capital Structure and Corporate Performance of Romanian Listed Companies. International Journal of Academic Research in Accounting, Finance and Management Sciences, 4(1), 287-292. https://doi.org/10.6007/IJARAFMS/v4-i1/629 
20. Myers, S. C. (1977). Determinats of Corporate Borrowing. Journal of Financial Economics, 5(2), 147175. https://doi.org/10.1016/0304-405X(77)90015-0

21. Nam, J. \& Wynne, K. (2006). The effect of agency costs on the value of single-segment and multi-segment firms. Journal of Corporate Finance, 12(4), 761-782. https://doi.org/10.1016/j.jcorpfin.2005.06.003

22. Nozari, A. (2016). The Impact of Financial Leverage on Agency Costs of Free Cash Flows in Listed Manufacturing Firms of Tehran Stock Exchange. The Turkish Online Journal of Design, Art and Communication, Special Edition, 2137-2144. https://doi.org/10.7456/1060AGSE/092

23. Opler, T. \& Titman, S. (1993). The determinants of leveraged buyout activity: Free cash flow vs financial distress costs. Journal of Finance, 48(5), 1985-1999. https://doi.org/10.1111/j.1540-6261.1993.tb05138.x

24. Pandey, K. D. \& Sahu, T. N. (2019). Debt Financing, Agency Cost and Firm Performance: Evidence from India. The Journal of Business Perspective, 23(3), 267-274. https://doi.org/10.1177/0972262919859203

25. Rashid, A. (2016). Managerial Ownership and Agency Cost: Evidence from Bangladesh. Journal of Business Ethics, 137(3), 609-621. https://doi.org/10.1007/s10551-015-2570-z

26. Savitri, E. (2018). Relationship between family ownership, agency costs towards financial performance and business strategy as mediation. Business: Theory and Practice, 19(2), 49-58. https://doi.org/10.3846/btp.2018.06

27. Seitz, N. \& Ellison, M. (1995). Capital Budgeting and Long-Term Financial Decisions. Dryden Press.

28. Vijayamohanan, P. N. (2016). Panel Data Analysis with Stata: Fixed Effects and Random Effects (MPRA Paper No. 76869). Munich: Munich Personal RePEc Archive.

29. Xiao, S. (2009). How Do Agency Costs Affect Firm Value? Evidence from China. SSRN Electronic Journal. https://doi.org/10.2139/ssrn.1865306

30. Wang, G. Y. (2010). The impact of free cash flows and agency costs on firm performance. Journal of Service Science and Management, 3(4), 408-418. https://doi.org/10.4236/jssm.2010.34047

31. Wellalage, N. H. \& Locke, S. (2012). An empirical investigation of agency costs and ownership structure in unlisted small businesses. New Zealand Journal of Applied Business Research, 10(2), 37-48.

32. Williams, J. (1987). Perquisites, risk, and capital structure. Journal of Finance, 42(1), 29-48. https://doi.org/10.1111/j.1540-6261.1987.tb02548.x 